\title{
Tabel Pokok Bahasan sebagai Alat Bantu Pencarian Buku Pelajaran di Perpustakaan Sekolah Menengah Atas
}

\author{
Ezra Putranda Setiawan ${ }^{1}$, Ismurjanti ${ }^{2}$ \\ SMA Negeri 8 Yogyakarta \\ 1e-mail: e2r4.ps@gmail.com \\ 2e-mail: ismoerjanti@gmail.com
}

\begin{abstract}
The change of the curriculum is one of the reasons behind the need to change the circulating books in the school library, especially in the elementary and secondary school. This condition often become important problem, since the library must spent much of its budget to buy the new books and provide enough space to keep the new books. On the other hand, further analysis show that the contents of the new curricula are similar to the previous curricula. In this research we construct "topic tables" in several subjects according to the 2013 Curriculum (with revision in 2016) at the level of Senior High School. Using this table, the book collection according the previous curriculum (i.e. the 2013 Curriculum, the Education Unit Level Curriculum 2006, and the Competence Based Curriculum 2004) could be used by the students, especially in the school library.
\end{abstract}

Keywords: school books, new curriculum, science, school library

\begin{abstract}
Abstrak
Salah satu konsekuensi pergantian kurikulum di jenjang pendidikan dasar dan menengah adalah pergantian buku pelajaran yang akan digunakan oleh para siswa. Hal ini tidak jarang merepotkan perpustakaan sekolah, khususnya dalam menyediakan buku pelajaran sesuai kurikulum terbaru dengan anggaran yang cenderung terbatas. Analisis secara mendalam menunjukkan bahwa materi-materi pelajaran kurikulum terbaru tidak jauh berbeda dengan kurikulum sebelumnya. Penelitian ini bertujuan untuk menyusun tabel pokok bahasan pada beberapa mata pelajaran sesuai Kurikulum 2013 (revisi 2016) jenjang Sekolah Menengah Atas (SMA)/sederajat. Menggunakan tabel tersebut, koleksi buku pelajaran pada kurikulum sebelumnya (Kurikulum 2013/Kurikulum Tingkat Satuan Pendidikan 2006/Kurikulum Berbasis Kompetensi 2004) yang masih tersedia di perpustakaan sekolah tetap dapat dimanfaatkan oleh para pemustaka.
\end{abstract}

Kata Kunci: buku pelajaran, kurikulum baru, MIPA, perpustakaan sekolah. 


\section{A. PENDAHULUAN}

Mencerdaskan kehidupan bangsa merupakan salah satu tujuan berdirinya Negara Kesatuan Republik Indonesia, sebagaimana tercantum dalam alinea IV pembukaan Undang-Undang Dasar (UUD) Negara Republik Indonesia 1945. Secara lebih jelas, pasal 31 UUD 1945 ayat 3 juga menyatakan bahwa pemerintah mengusahakan dan menyelenggarakan satu sistem pendidikan nasional, yang meningkatkan keimanan dan ketakwaan serta akhlak mulia dalam rangka mencerdaskan kehidupan bangsa yang diatur dengan undang-undang.

Salah satu bentuk usaha pemerintah dalam penyelenggaraan sistem pendidikan nasional adalah dengan menetapkan kurikulum. Menurut Susilana dkk. (2006), istilah kurikulum berasal dari kata latin curere yang berarti tempat berpacu, yakni jarak yang harus ditempuh seorang pelari dari start sampai dengan finish untuk memperoleh penghargaan. Berdasarkan pengertian tersebut, kurikulum dapat dipahami sebagai sejumlah mata pelajaran yang harus ditempuh seorang siswa dari awal hingga akhir program pelajaran untuk memperoleh ijazah. Pengertian lain yang lebih luas mengenai kurikulum dikemukakan oleh Hilda (dalam Ali, 2008), yang menyebutkan bahwa kurikulum merupakan rencana pembelajaran (a plan for learning), sehingga tersusun oleh hal-hal yang diketahui terkait dengan proses pembelajaran maupun perkembangan individu. Lebih lanjut, Undang-undang nomor 20 tahun 2003 tentang Sistem Pendidikan Nasional, kurikulum adalah seperangkat rencana dan pengaturan mengenai tujuan, materi/isi atau bahan pelajaran, serta metode cara yang digunakan sebagai pedoman penyelenggaraan kegiatan pembelajaran untuk mencapai tujuan pendidikan. Secara umum, suatu kurikulum memuat pokok-pokok bahasan serta standar yang harus dipenuhi oleh siswa pada setiap periode dalam setiap jenjang pendidikan.

Sampai dengan tahun 2018, pemerintah Republik Indonesia telah melakukan perom-bakan kurikulum sebanyak delapan kali (Wirianto, 2014). Kurikulum pertama yang berbahasa Indonesi, yakni kurikulum 1947, berturut-turut diganti dengan kurikulum 1968 lalu menjadi kurikulum 1975. Sejak saat itu, pergantian kurikulum berlangsung tiap sekitar 10 tahun, yang ditandai dengan munculnya kurikulum 1984, diikuti oleh kurikulum 1994 yang kemudian disempurnakan pada tahun 1999 (Khanafi, 2013). Pada tahun 2002, terjadi perubahan sistem tahun ajaran di jenjang pendidikan dasar dan menengah dari model catur wulan (cawu) menjadi model semester. 
Perubahan kebijakan pasca reformasi memungkinkan sejumlah sekolah di Indonesia mengadopsi kurikulum internasional, misalnya kurikulum International Baccalaureate (IB), kurikulum internasional Cambridge, kurikulum International Primary (IPC), dan berbagai kurikulum lainnya (https://squlio.com/kurikulum-internasional-di-indonesia/ diakses pada tanggal 30 Juni 2018). Pada tahun 2004, muncullah Kurikulum Berbasis Kompetensi (KBK) yang hanya berusia dua tahun, dan digantikan oleh Kurikulum Tingkat Satuan Pendidikan (KTSP) pada tahun 2006 (Widuri, 2012). Pada tahun 2013, kurikulum baru yang disebut sebagai "Kurikulum 2013" dengan segala kontroversinya diperkenalkan dan diujicobakan pada sejumlah sekolah. Pada waktu itu, sekolah-sekolah yang tidak menjadi lokasi uji coba Kurikulum 2013 tetap menggunakan KTSP 2006. Kurikulum 2013 ini ternyata juga hanya berumur singkat, karena pada tahun 2016 muncul Peraturan Menteri Pendidikan Republik Indonesia nomor 20, 21, 22, dan 23 tahun 2016 berturut-turut tentang Standar Kelulusan, Standar Isi, Standar Proses, dan Standar Penilaian yang memuat revisi besar atas kurikulum 2013. Dewasa ini, kurikulum 2013 revisi 2016 inilah yang digunakan secara luas di Indonesia.

Pergantian kurikulum dalam waktu singkat, baik dari Kurikulum 2013 ke Kurikulum 2013 revisi 2016 maupun dari KBK 2004 ke KTSP 2006 menimbulkan kebutuhan buku-buku pelajaran yang sesuai dengan kurikulum terbaru. Perpustakaan sekolah sebagai salah satu unit kerja dengan tugas menyediakan informasi yang menunjang keberhasilan kegiatan belajar mengajar di sekolah tentu perlu menyediakan buku-buku pelajaran ini sesuai dengan jumlah siswa yang ada (Komariah, 2009; Rosyada, 2004). Terlebih, perpustakaan sekolah juga dipandang sebagai sumber ilmu pengetahuan, pusat kegiatan belajar, dan sumber ide-ide baru bagi warga sekolah (Mangnga, 2015). Riset menunjukkan bahwa ketidaklengkapan koleksi merupakan salah satu hambatan dalam upaya meningkatkan minat kunjung siswa ke perpustakaan sekolah (Yusuf, 2017). Padahal, Nuriyah (2017) menyebutkan bahwa ketersediaan koleksi di perpustakaan sekolah berkorelasi positif secara signifikan terhadap kunjungan siswa maupun prestasi belajar.

Bagi sekolah-sekolah dengan anggaran perpustakaan terbatas, pengadaan buku-buku sesuai kurikulum terbaru dapat menjadi beban yang cukup berat. Di satu sisi, terdapat buku-buku terbitan pemerintah yang dapat dibeli dengan dana Bantuan Operasional Sekolah (BOS). Di sisi lain, bukubuku terbitan pemerintah sesuai Kurikulum 2013 revisi 2016 untuk jenjang Sekolah Menengah Atas (SMA)/Madrasah Aliyah (MA) hanya tersedia pada 
kelompok mata pelajaran wajib, yakni Matematika, Bahasa Indonesia, Bahasa Inggris, Pendidikan Agama dan Budi Pekerti, Pendidikan Pancasila dan Kewarganegaraan, Seni Budaya, serta Pendidikan Jasmani, Olahraga, dan Kesehatan. Tidak diterbitkannya buku-buku mata pelajaran peminatan oleh Pemerintah menyebabkan perpustakaan sekolah perlu membeli buku terbitan swasta, yang tidak jarang memiliki harga lebih tinggi dibandingkan buku-buku terbitan pemerintah. Beban anggaran tersebut semakin terasa berat bila perpustakaan sekolah diminta menyediakan buku-buku berkualitas tinggi sejumlah seluruh siswa di sekolah tersebut.

Di samping kendala anggaran, tidak jarang perpustakaan sekolah hanya memiliki kapasitas ruang yang terbatas. Akibatnya, penggantian koleksi dengan buku-buku kurikulum terbaru tentu menyebabkan perpustakaan harus segera melakukan penyiangan koleksi demi menyediakan ruang bagi buku-buku baru. Penyiangan koleksi yang terlalu sering atau dilakukan dalam waktu singkat (umur buku cukup pendek) tentu bukanlah pilihan yang menyenangkan, apalagi bila kondisi buku masih cukup baik dan layak dibaca. Perpustakaan juga tidak dapat menjual buku-buku pelajaran tersebut dengan harga yang layak, mengingat pergantian kurikulum menyebabkan buku-buku tersebut dianggap usang. Terdapat kerugian materi dan waktu bila buku-buku pelajaran tersebut harus disiangi dalam kondisi utuh.

Di sisi lain, bila melihat singkatnya masa berlaku kurikulum 2013, tidak ada jaminan bahwa buku-buku kurikulum 2013 revisi 2016 akan dipergunakan dalam jangka waktu lama. Buku pelajaran Kurikulum 2013 yang diterbitkan Kementerian Pendidikan dan Kebudayaan pun telah mengalami revisi dari tahun ke tahun. Oleh karena itu, diperlukan solusi agar buku-buku kurikulum lama yang masih relevan di perpustakaan sekolah tetap dapat dimanfaatkan oleh para pemustaka, khususnya para siswa, sebagai buku penunjang pelajaran.

Kajian mendalam pada kompetensi inti masing-masing mata pelajaran menunjukkan bahwa perubahan kurikulum hanya menyebabkan perubahan urutan penyampaian suatu pokok bahasan dalam suatu mata pelajaran. Sebagai contoh, materi Fungsi Komposisi dan Fungsi Invers yang mula-mula diberikan dalam mata pelajaran Matematika kelas XI semester II, pada kurikulum terbaru diberikan dalam mata pelajaran Matematika kelas X. Contoh lain, materi Kimia Organik dan Minyak Bumi yang mula-mula diberikan di kelas X, dalam kurikulum 2013 revisi 2016 disampaikan di kelas XI semester I. Oleh karena itu, masuk akal bila buku-buku pelajaran dalam 
kurikulum lama masih dapat dimanfaatkan oleh para siswa sebagai penunjang pelajaran.

Tantangan utama dalam menggunakan buku pelajaran kurikulum lama adalah menemu-kan buku yang memuat pokok bahasan tertentu. Diperlukan upaya untuk memudahkan siswa menemukan buku pelajaran yang memuat pokok bahasan tertentu. Proses ini, yang dapat dipandang sebagai proses penelusuran pustaka atau bantuan pemustaka, tentu merupakan tugas pustakawan (Wahyuni, 2015). Di sisi lain, luasnya ruang lingkup mata pelajaran maupun banyaknya mata pelajaran di tingkat sekolah menengah menyebabkan pustakawan sekolah akan menghadapi kesulitan untuk menghafalkan seluruh pokok bahasan. Banyaknya siswa yang memerlukan bantuan untuk penelusuran pustaka juga merupakan tantangan, terlebih bila pustakawan yang ada juga merangkap sebagai guru mata pelajaran sehingga tidak dapat selalu berada di perpustakaan.

Penelitian ini bertujuan untuk mendokumentasikan sebaran materi pelajaran jenjang Sekolah Menengah Atas (SMA) berdasarkan buku-buku pelajaran dari beberapa kurikulum yang seringkali masih tersedia di perpustakaan sekolah, yakni kurikulum 2013, kurikulum tingkat satuan pendidikan (KTSP) 2006, kurikulum berbasis kompetensi (KBK) 2004, dan kurikulum 1994 dengan suplemen GBPP 1999. Data sebaran materi ini dapat digunakan oleh pustakawan maupun para pemustaka untuk mencari buku yang memuat pokok bahasan terten-tu sesuai kurikulum 2013 revisi 2016. Dengan demikian, perpustakaan sekolah yang belum memiliki buku-buku sesuai kurikulum 2013 revisi 2016 dapat menggunakan buku-buku yang telah tersedia secara lebih optimal.

Penelitian ini bersifat kualitatif, dilakukan dengan metode telaah pustaka dan dokumen-tasi pada buku-buku pelajaran tingkat Sekolah Menengah Atas (SMA) atau Madrasah Aliyah (MA). Sebagai bahan dalam riset ini adalah buku mata pelajaran kelas X, kelas XI, dan kelas XII SMA sesuai Kurikulum 2013 revisi 2016, buku mata pelajaran sesuai kurikulum 2013, buku mata pelajaran sesuai kurikulum tingkat satuan pendidikan (KTSP) 2006, buku mata pelajaran sesuai kurikulum berbasis kompetensi (KBK) 2004, dan buku mata pelajaran sesuai kurikulum 1994 dengan suplemen GBPP 1999. Walaupun belum ada penelitian empiris mengenai rata-rata usia buku di perpustakaan sekolah, berdasarkan pengalaman peneliti buku-buku pelajaran yang berusia di bawah 20 tahun masih dapat dijumpai di sejumlah perpustakaan sekolah dalam kondisi relatif baik. 
Buku-buku yang telah dipilih kemudian dianalisis untuk melihat sebaran pokok bahasan pada setiap jenjang dan setiap mata pelajaran. Berdasarkan tabel Kompetensi Inti Kurikulum 2013 revisi 2016, dibentuk tabel-tabel sebaran pokok bahasan tiap mata pelajaran. Sebaran pokok bahasan pada kurikulum terbaru ini kemudian dicocokkan dengan sebaran pokok bahasan pada buku-buku pelajaran dari kurikulum yang berlaku pada periode sebelumnya. Guna menghindari konflik kepentingan dengan perusahaan/lembaga penerbit buku pelajaran maupun penulis buku pelajaran, identitas buku yang digunakan tidak dicantumkan dalam artikel ini.

\section{B. HASIL DAN PEMBAHASAN}

Dalam pembahasan ini akan disajikan kesetaraan pokok bahasan dalam mata pelajaran Biologi, Kimia, Fisika, dan Matematika di tingkat Sekolah Menengah Atas (SMA) sesuai kurikulum 2013 revisi tahun 2016.

\section{Biologi}

Kesetaraan pokok bahasan pada mata pelajaran Biologi tingkat SMA dapat dilihat pada tabel 1, tabel 2, dan tabel 3 berikut.

Tabel 1. Keseteraan Pokok Bahasan Mata Pelajaran Biologi kelas X

\begin{tabular}{|c|c|c|c|c|}
\hline \multirow[b]{2}{*}{ Pokok Bahasan } & \multicolumn{4}{|c|}{ Buku Kimia sesuai Masing-masing Kurikulum } \\
\hline & 2013 & $\begin{array}{c}\text { KTSP } \\
2006\end{array}$ & $\begin{array}{l}\text { KBK } \\
2004\end{array}$ & $1994 / 1999$ \\
\hline \multicolumn{5}{|l|}{ Semester I } \\
\hline Ruang Lingkup Biologi & \multirow{5}{*}{ X sem. 1} & $\mathrm{X}$ sem. 1 & $\mathrm{X} \mathrm{sem.} 1$ & $\mathrm{X}$ sem. 1 \\
\hline Keanekaragaman Hayati & & $\mathrm{X}$ sem. 2 & $\mathrm{X} \mathrm{sem.} 2$ & X sem. 2 \\
\hline Virus dan Monera & & \multirow{3}{*}{$\mathrm{X}$ sem. 1} & \multirow{3}{*}{ X sem. 1} & \multirow{3}{*}{ X sem. 1} \\
\hline Protista & & & & \\
\hline Fungi & & & & \\
\hline \multicolumn{5}{|l|}{ Semester II } \\
\hline Tumbuhan & \multirow{4}{*}{ X sem. 2} & \multirow{4}{*}{ X sem. 2} & \multirow{4}{*}{ X sem. 2} & \multirow{4}{*}{$\mathrm{X}$ sem. 2} \\
\hline Hewan & & & & \\
\hline Ekologi & & & & \\
\hline Lingkungan Hidup & & & & \\
\hline
\end{tabular}


Tabel 2. Kesetaraan Pokok Bahasan Mata Pelajaran Biologi kelas XI

\begin{tabular}{|c|c|c|c|c|}
\hline \multirow[b]{2}{*}{ Pokok Bahasan } & \multicolumn{4}{|c|}{ Buku Kimia sesuai Masing-masing Kurikulum } \\
\hline & 2013 & $\begin{array}{l}\text { KTSP } \\
2006\end{array}$ & KBK 2004 & $1994 / 1999$ \\
\hline \multicolumn{5}{|l|}{ Semester I } \\
\hline Sel & \multirow{6}{*}{ XI sem. 1} & \multirow{5}{*}{ XI sem. 1} & \multirow{5}{*}{ XI sem. 1} & XII sem. 1 \\
\hline $\begin{array}{ll}\text { Struktur } & \text { Jaringan } \\
\text { Tumbuhan } & \end{array}$ & & & & \multirow{4}{*}{ XI sem. 1} \\
\hline Struktur Jaringan Hewan & & & & \\
\hline Sistem Gerak & & & & \\
\hline Sistem Sirkulasi & & & & \\
\hline Sistem Pencernaan & & XI sem. 2 & XI sem. 2 & XI sem. 2 \\
\hline \multicolumn{5}{|l|}{ Semester II } \\
\hline Sistem Pernapasan & \multirow{5}{*}{ XI sem. 2} & \multirow{5}{*}{ XI sem. 2} & \multirow{5}{*}{ XI sem. 2} & \multirow{5}{*}{ XI sem. 2} \\
\hline Sistem Ekskresi & & & & \\
\hline Sistem Koordinasi & & & & \\
\hline Sistem Reproduksi & & & & \\
\hline Sistem Pertahanan Tubuh & & & & \\
\hline
\end{tabular}

Tabel 3. Keseteraan Pokok Bahasan Mata Pelajaran Biologi kelas XII

\begin{tabular}{|c|c|c|c|c|}
\hline \multirow{2}{*}{ Pokok Bahasan } & \multicolumn{4}{|c|}{ Buku Kimia sesuai Masing-masing Kurikulum } \\
\hline & 2013 & KTSP 2006 & KBK 2004 & 1994/1999 \\
\hline \multicolumn{5}{|l|}{ Semester I } \\
\hline $\begin{array}{ll}\text { Pertumbuhan } & \text { dan } \\
\text { Perkembangan } & \end{array}$ & \multirow{5}{*}{$\begin{array}{c}\text { XII sem. } \\
1\end{array}$} & \multirow{5}{*}{ XII sem. 1} & \multirow{5}{*}{ XII sem. 1} & XII sem. 1 \\
\hline Metabolisme Sel & & & & \multirow{4}{*}{ XII sem. 1} \\
\hline Pembelahan Sel & & & & \\
\hline Substansi Genetika & & & & \\
\hline Pola-Pola Hereditas & & & & \\
\hline Semester II & & & & \\
\hline
\end{tabular}


158 | Ezra Putranda Setiawan dan Ismurjanti Ismurjanti: Tabel Pokok...

\begin{tabular}{|l|c|c|c|c|}
\hline Mutasi & XII sem. \\
2 & XII sem. 2 & XII sem. 2 & XII sem. 2 \\
\cline { 1 - 4 } Evolusi & & & \\
\hline
\end{tabular}

Dari tabel 1, tabel 2, dan tabel 3 di atas, terlihat bahwa sebagian besar materi Biologi SMA tidak mengalami perubahan, sehingga buku-buku kurikulum lama secara terpaksa masih dapat digunakan di perpustakaan.

\section{Kimia}

Kesetaraan pokok bahasan pada mata pelajaran Kimia tingkat SMA dapat dilihat pada tabel 1 , tabel 2 , dan tabel 3 berikut.

Tabel 1. Keseteraan Pokok Bahasan Mata Pelajaran Kimia kelas X

\begin{tabular}{|c|c|c|c|c|}
\hline \multirow[b]{2}{*}{ Pokok Bahasan } & \multicolumn{4}{|c|}{ Buku Kimia sesuai Masing-masing Kurikulum } \\
\hline & 2013 & $\begin{array}{l}\text { KTSP } \\
2006\end{array}$ & KBK 2004 & $1994 / 1999$ \\
\hline \multicolumn{5}{|l|}{ Semester I } \\
\hline Pengantar Kimia & \multirow{3}{*}{ X sem. 1} & X sem. 1 & $\mathrm{X}$ sem. 1 & $\mathrm{X}$ sem. 1 \\
\hline $\begin{array}{l}\text { Struktur Atom dan } \\
\text { Sistem Periodik Unsur }\end{array}$ & & $\begin{array}{l}\text { X sem. } 1+ \\
\text { XI sem. } 1\end{array}$ & $\begin{array}{l}\text { X sem. } 1+ \\
\text { XI sem. } 1\end{array}$ & $\begin{array}{l}\text { X sem. } 1+ \\
\text { XII sem. } 1\end{array}$ \\
\hline Ikatan Kimia & & $\mathrm{X}$ sem. 1 & $\mathrm{X}$ sem. 1 & X sem. 2 \\
\hline \multicolumn{5}{|l|}{ Semester II } \\
\hline Larutan elektrolit & \multirow{3}{*}{$X$ sem. 2} & $\mathrm{X}$ sem. 2 & $\mathrm{X}$ sem. 2 & XI sem. 1 \\
\hline Stoikiometri & & $\mathrm{X}$ sem. 1 & $\mathrm{X}$ sem. 1 & X sem. 1 \\
\hline Reaksi Redoks & & X sem. 2 & $\mathrm{X}$ sem. 2 & X sem. 2 \\
\hline
\end{tabular}

Tabel 2. Keseteraan Pokok Bahasan Mata Pelajaran Kimia kelas XI

\begin{tabular}{|l|c|c|c|c|}
\hline \multirow{2}{*}{ Pokok Bahasan } & \multicolumn{3}{|c|}{ Buku Kimia sesuai Masing-masing Kurikulum } \\
\cline { 2 - 5 } & 2013 & $\begin{array}{c}\text { KTSP } \\
2006\end{array}$ & $\begin{array}{c}\text { KBK } \\
2004\end{array}$ & $1994 / 1999$ \\
\hline Semester I & & X sem. 2 & X sem. 2 & X sem. 2 \\
\hline $\begin{array}{l}\text { Hidrokarbon dan Minyak } \\
\text { Bumi }\end{array}$ & XI sem. 1 & & \\
\hline
\end{tabular}




\begin{tabular}{|c|c|c|c|c|}
\hline Termokimia & & \multirow{3}{*}{ XI sem. 1} & \multirow{3}{*}{ XI sem. 1} & \multirow{3}{*}{ XI sem. 1} \\
\hline Laju Reaksi & & & & \\
\hline Kesetimbangan Kimia & & & & \\
\hline \multicolumn{5}{|l|}{ Semester II } \\
\hline Asam dan Basa & \multirow{4}{*}{ XI sem. 2} & \multirow{4}{*}{ XI sem. 2} & \multirow{4}{*}{ XI sem. 2} & XI sem. 1 \\
\hline Larutan Penyangga & & & & XII sem. 1 \\
\hline Hidrolisis Garam & & & & XII sem. 1 \\
\hline Koloid & & & & XI sem. 2 \\
\hline
\end{tabular}

Tabel 3. Keseteraan Pokok Bahasan Mata Pelajaran Kimia kelas XII

\begin{tabular}{|c|c|c|c|c|}
\hline \multirow[b]{2}{*}{ Pokok Bahasan } & \multicolumn{4}{|c|}{ Buku Kimia sesuai Masing-masing Kurikulum } \\
\hline & 2013 & $\begin{array}{l}\text { KTSP } \\
2006\end{array}$ & $\begin{array}{l}\text { KBK } \\
2004\end{array}$ & $1994 / 1999$ \\
\hline \multicolumn{5}{|l|}{ Semester I } \\
\hline \multicolumn{5}{|l|}{ Sifat koligatif larutan } \\
\hline $\begin{array}{lll}\text { Reaksi redoks } & \text { dan } \\
\text { elektrokimia } & & \end{array}$ & \multirow[t]{2}{*}{ XII sem. 1} & \multirow[t]{2}{*}{ XII sem. 1} & \multirow[t]{2}{*}{ XII sem. 1} & \multirow[t]{2}{*}{ XII sem. 1} \\
\hline Kimia Unsur & & & & \\
\hline \multicolumn{5}{|l|}{ Semester II } \\
\hline Senyawa karbon & \multirow{3}{*}{ XII sem. 2} & \multirow{3}{*}{ XII sem. 2} & \multirow{3}{*}{ XII sem. 2} & XI sem. 2 \\
\hline Benzena dan turunannya & & & & \multirow{2}{*}{ XII sem. 2} \\
\hline Makromolekul & & & & \\
\hline
\end{tabular}

Dari uraian di atas, terlihat bahwa susunan sebagian besar materi pelajaran Kimia SMA, khususnya di kelas kelas XI dan XII sesuai kurikulum KBK 2004 tidak mengalami perubahan hingga masa kurikulum 2013 revisi 2016 yang digunakan saat ini. Di samping itu, pada kurikulum terbaru ini tidak terdapat materi atau bahan ajar yang belum dijumpai pada kurikulumkurikulum sebelumnya.

Dengan demikian, buku-buku Kimia SMA sesuai Kurikulum Berbasis Kompetensi (KBK) 2004, Kurikulum Tingkat Satuan Pendidikan (KTSP) 
160 | Ezra Putranda Setiawan dan Ismurjanti Ismurjanti: Tabel Pokok...

2006, maupun Kurikulum 2013 tetap dapat digunakan pada kurikulum 2013 revisi 2016.

\section{Fisika}

Kesetaraan pokok bahasan pada mata pelajaran Fisika tingkat SMA dapat dilihat pada tabel 4, tabel 5, dan tabel 6 di bawah ini.

Tabel 4. Keseteraan Pokok Bahasan Mata Pelajaran Fisika kelas X

\begin{tabular}{|c|c|c|c|c|}
\hline \multirow[b]{2}{*}{ Pokok Bahasan } & \multicolumn{4}{|c|}{ Buku Fisika sesuai Masing-masing Kurikulum } \\
\hline & 2013 & $\begin{array}{l}\text { KTSP } \\
2006\end{array}$ & KBK 2004 & 1994/1999 \\
\hline \multicolumn{5}{|l|}{ Semester I } \\
\hline $\begin{array}{l}\text { Hakikat Fisika dan } \\
\text { Pengukuran }\end{array}$ & \multirow{3}{*}{ X sem. 1} & \multirow{3}{*}{ X sem. 1} & \multirow{3}{*}{ X sem. 1} & \multirow{5}{*}{ X sem. 1} \\
\hline Vektor & & & & \\
\hline Gerak Lurus & & & & \\
\hline Gerak Parabola & XI sem. 1 & XI sem. 1 & XI sem. 1 & \\
\hline Gerak Melingkar & X sem. 1 & X sem. 1 & X sem. 1 & \\
\hline \multicolumn{5}{|l|}{ Semester II } \\
\hline Gaya Gravitasi & XI sem. 1 & XI sem. 1 & XI sem. 1 & X sem. 1 \\
\hline Usaha dan Energi & XI sem. 1 & XI sem. 2 & XI sem. 2 & \multirow{3}{*}{$X$ sem. 2} \\
\hline Impuls dan Momentum & XI sem. 1 & \multirow{2}{*}{ XI sem. 1} & \multirow{2}{*}{ XI sem. 1} & \\
\hline Getaran Harmonis & XI sem. 1 & & & \\
\hline
\end{tabular}

Tabel 5. Keseteraan Pokok Bahasan Mata Pelajaran Fisika kelas XI

\begin{tabular}{|l|c|c|c|c|}
\hline \multirow{2}{*}{ Pokok Bahasan } & \multicolumn{4}{c|}{ Buku Fisika sesuai Masing-masing Kurikulum } \\
\cline { 2 - 5 } & 2013 & $\begin{array}{c}\text { KTSP } \\
2006\end{array}$ & $\begin{array}{c}\text { KBK } \\
2004\end{array}$ & $1994 / 1999$ \\
\hline Semester I & \multicolumn{5}{|c|}{} \\
\hline $\begin{array}{l}\text { Gerak Rotasi dan } \\
\text { Keseimbangan }\end{array}$ & XI sem. 2 & XI sem. 2 & XI sem. 2 & XII sem. 1 \\
\hline Elastisitas & X sem. 2 & XI sem. 1 & XI sem. 1 & X sem. 2 \\
\hline
\end{tabular}




\begin{tabular}{|c|c|c|c|c|}
\hline Fluida Statis & & XI sem. 2 & XI sem. 2 & \\
\hline Suhu dan Kalor & & X sem. 2 & $\mathrm{X}$ sem. 2 & \\
\hline \multicolumn{5}{|l|}{ Semester II } \\
\hline Teori Kinetik Gas & XI sem. 2 & \multirow{2}{*}{ XI sem. 2} & \multirow{2}{*}{ XI sem. 2} & \multirow{3}{*}{ XII sem. 1} \\
\hline Termodinamika & XI sem. 2 & & & \\
\hline Gelombang Mekanik & \multirow{2}{*}{$\begin{array}{c}\text { XII sem. } \\
1\end{array}$} & \multirow{2}{*}{ XII sem. 1} & \multirow{2}{*}{ XII sem. 1} & \\
\hline Gelombang Bunyi & & & & X sem. 2 \\
\hline Cahaya dan Alat Optik & $\mathrm{X}$ sem. 2 & X sem. 2 & X sem. 2 & XI sem. 2 \\
\hline
\end{tabular}

Tabel 6. Keseteraan Pokok Bahasan Mata Pelajaran Fisika kelas XII

\begin{tabular}{|c|c|c|c|c|}
\hline \multirow[b]{2}{*}{ Pokok Bahasan } & \multicolumn{4}{|c|}{ Buku Fisika sesuai Masing-masing Kurikulum } \\
\hline & 2013 & $\begin{array}{l}\text { KTSP } \\
2006\end{array}$ & $\begin{array}{l}\text { KBK } \\
2004\end{array}$ & $1994 / 1999$ \\
\hline \multicolumn{5}{|l|}{ Semester I } \\
\hline Listrik Statis & \multirow{5}{*}{ XII sem. 1} & XII sem. 1 & XII sem. 1 & XI sem. 1 \\
\hline Listrik Arus Searah & & $\mathrm{X}$ sem. 2 & $\mathrm{X}$ sem. 2 & XI sem. 1 \\
\hline Medan Magnet & & \multirow{3}{*}{ XII sem. 1} & \multirow{3}{*}{ XII sem. 1} & XI sem. $1+$ \\
\hline Induksi Elektromagnetik & & & & XII sem. 1 \\
\hline Listrik Arus Bolak-balik & & & & XII sem. 1 \\
\hline \multicolumn{5}{|l|}{ Semester II } \\
\hline $\begin{array}{l}\text { Gelombang } \\
\text { elektromagnetik }\end{array}$ & \multirow{4}{*}{ XII sem. 2} & XII sem. 1 & XII sem. 1 & XII sem. 2 \\
\hline Fisika kuantum & & \multirow{3}{*}{ XII sem. 2} & \multirow{3}{*}{ XII sem. 2} & \\
\hline Relativitas khusus & & & & \\
\hline Atom dan Inti atom & & & & \\
\hline
\end{tabular}

Dari uraian di atas, terlihat bahwa susunan materi pelajaran Fisika di tingkat SMA mengalami perubahan yang cukup besar dari satu kurikulum ke kurikulum berikutnya. Hanya beberapa materi di kelas X semester I (misal pengukuran, vektor, gerak lurus) dan di kelas XII semester II (misal fisika kuantum, teori relativitas khusus, dan strutkur atom) yang relatif kurang 
mengalami perubahan. Di sisi lain, terdapat dua pokok bahasan pada kurikulum 2013 revisi 2016 yang tidak dijumpai pada buku-buku kurikulum sebelumnya, yakni teknologi digital (materi kelas XII) dan pemanasan global (materi kelas XI). Oleh karena itu, buku-buku kelas X semester I dan kelas XII semester II yang tersedia di perpustakaan sekolah masih dapat dimanfaatkan dengan mudah oleh para siswa.

Sebagai catatan, pada kurikulum 2013 tidak ada buku pegangan wajib atau buku paket mata pelajaran Fisika SMA yang dikeluarkan oleh Kementerian Pendidikan dan Kebudayaan (Kemendikbud) Republik Indonesia, sedangkan buku-buku yang tersedia di pasaran dengan label kurikulum 2013 tidak memberikan urutan materi yang sama. Tabel di atas berlaku untuk buku-buku Fisika SMA kurikulum 2013 yang sesuai dengan Peraturan Menteri Pendidikan dan Kebudayaan Republik Indonesia nomor 64, 65, dan 66 tahun 2013 tentang standar isi, standar proses, dan standar penilaian jenjang pendidikan dasar hingga pendidikan menengah di Indonesia.

\section{Matematika}

Sesuai Kurikulum 2013 revisi 2016, pelajaran Matematika di tingkat SMA dapat dibedakan menjadi dua bagian, yakni Matematika Wajib (wajib diberikan untuk semua siswa SMA) dan Matematika Peminatan (wajib diberikan pada siswa SMA dengan peminatan Matematika dan Ilmu Pengetahuan Alam, namun dapat menjadi pilihan bagi siswa dengan minatminat lainnya). Kesetaraan pokok bahasan pada mata pelajaran Matematika Wajib tingkat SMA dapat dilihat pada tabel 7, tabel 8, dan tabel 9 di bawah ini. Penggolongan pada buku-buku Kurikulum Tingkat Satuan Pendidikan (KTSP) 2006 dan kurikulum sebelumnya mengacu pada buku kelas XI dan XII SMA program Ilmu Pengetahuan Alam (IPA).

Tabel 7. Keseteraan Pokok Bahasan Mata Pelajaran Matematika Wajib kelas $\mathrm{X}$

\begin{tabular}{|c|c|c|c|c|}
\hline \multirow{2}{*}{ Pokok Bahasan } & \multicolumn{4}{|c|}{$\begin{array}{c}\text { Buku Matematika sesuai Masing-masing } \\
\text { Kurikulum }\end{array}$} \\
\hline & 2013 & $\begin{array}{c}\text { KTSP200 } \\
6\end{array}$ & KBK 2004 & $1994 / 1999$ \\
\hline \multicolumn{5}{|l|}{ Semester I } \\
\hline $\begin{array}{lr}\text { Persamaan } & \text { dan } \\
\text { Pertidaksamaan Nilai Mutlak }\end{array}$ & \multirow{2}{*}{$\begin{array}{c}\text { X sem. } \\
1\end{array}$} & \multirow[t]{2}{*}{$\mathrm{X}$ sem. 1} & \multirow[t]{2}{*}{ X sem. 1} & Tidak ada \\
\hline Pertidaksamaan & & & & Tidak ada \\
\hline
\end{tabular}




\begin{tabular}{|l|c|c|c|c|}
\hline Rasional/Irasional & \multirow{2}{*}{} & & \\
\cline { 1 - 3 } $\begin{array}{l}\text { Sistem Persamaan Linear } \\
\text { Tiga Variabel }\end{array}$ & & & X sem. 2 \\
\cline { 1 - 3 } Pertidaksamaan dua variabel & & Tidak ada & Tidak ada & Tidak ada \\
\hline Fungsi komposisi dan invers & $\begin{array}{c}\text { XI sem. } \\
1\end{array}$ & XI sem. 2 & XI sem. 2 & XI sem. 1 \\
\hline Semester II & $\begin{array}{c}\text { X sem. } \\
2\end{array}$ & X sem. 2 & X sem. 2 & X sem. 1 \\
\hline Trigonometri & & & \\
\hline
\end{tabular}

Tabel 8. Keseteraan Pokok Bahasan Mata Pelajaran Matematika Wajib kelas XI

\begin{tabular}{|c|c|c|c|c|}
\hline \multirow[b]{2}{*}{ Pokok Bahasan } & \multicolumn{4}{|c|}{ Buku Matematika sesuai Masing-masing Kurikulum } \\
\hline & 2013 & $\begin{array}{c}\text { KTSP } \\
2006\end{array}$ & KBK 2004 & 1994/1999 \\
\hline \multicolumn{5}{|l|}{ Semester I } \\
\hline Induksi matematika & XII sem. 2 & $\mathrm{X}$ sem. 2 & $\mathrm{X}$ sem. 2 & XII sem. 2 \\
\hline Program Linear & XI sem. 1 & \multirow{3}{*}{ XII sem. 1} & \multirow{3}{*}{ XII sem. 1} & XI sem. 2 \\
\hline Matriks & XII sem. 1 & & & X sem. 2 \\
\hline Transformasi Geometri & XI sem. 1 & & & XII sem. 2 \\
\hline Barisan dan Deret & XII sem. 2 & XII sem. 1 & XII sem. 1 & X sem. 2 \\
\hline \multicolumn{5}{|l|}{ Semester II } \\
\hline Limit fungsi aljabar & \multirow{3}{*}{ XI sem. 2} & \multirow{2}{*}{ XI sem. 2} & \multirow{2}{*}{ XI sem. 2} & \multirow{2}{*}{ XI sem. 2} \\
\hline Turunan fungsi aljabar & & & & \\
\hline $\begin{array}{l}\text { Integral tak tentu fungsi } \\
\text { aljabar }\end{array}$ & & XII sem. 1 & XII sem. 1 & XII sem. 1 \\
\hline
\end{tabular}

Tabel 9. Keseteraan Pokok Bahasan Mata Pelajaran Matematika Wajib kelas XII

Pokok Bahasan Buku Matematika sesuai Masing-masing Kurikulum

\begin{tabular}{|l|l|l|l|}
\hline 2013 & KTSP & KBK 2004 & $1994 / 1999$ \\
\hline
\end{tabular}


164 | Ezra Putranda Setiawan dan Ismurjanti Ismurjanti: Tabel Pokok...

\begin{tabular}{|c|c|c|c|c|}
\hline & & 2006 & & \\
\hline \multicolumn{5}{|l|}{ Semester I } \\
\hline Dimensi tiga & XII sem. 1 & X sem. 2 & X sem. 2 & XII sem. 2 \\
\hline Statistika & X sem. 2 & XI sem. 1 & XI sem. 1 & XI sem. 1 \\
\hline \multicolumn{5}{|l|}{ Semester II } \\
\hline Peluang & XI sem. 2 & XI sem. 1 & XI sem. 1 & XI sem. 1 \\
\hline
\end{tabular}

Kesetaraan pokok bahasan pada mata pelajaran Matematika Peminatan tingkat SMA dapat dilihat pada tabel 10, tabel 11, dan tabel 12 berikut. Seperti pada tabel 7, tabel 8, dan tabel 9, penggolongan buku pelajaran sesuai dengan KTSP 2006, KBK 2004, dan kurikulum 1994 GBPP 1999 mengacu pada buku-buku Matematika untuk Program Ilmu Pengetahuan Alam (IPA).

Tabel 10. Keseteraan Pokok Bahasan Mata Pelajaran Matematika Peminatan kelas X

\begin{tabular}{|l|c|c|c|c|}
\hline \multirow{2}{*}{\multicolumn{1}{|c|}{ Pokok Bahasan }} & \multicolumn{3}{c|}{ Buku Matematika sesuai Masing-masing Kurikulum } \\
\cline { 2 - 5 } & 2013 & $\begin{array}{c}\text { KTSP } \\
2006\end{array}$ & KBK 2004 & $1994 / 1999$ \\
\hline Semester I & X sem. 1 & X sem. 1 & X sem. 1 & X sem. 1 \\
\hline Eksponen dan Logaritma & X sem. 2 & XII sem. 2 & XII sem. 2 & XI sem. 2 \\
\hline Fungsi Eksponen & \multicolumn{5}{|l}{} \\
\hline Fungsi Logaritma & XII sem. 1 & XII sem. 1 & XII sem. 1 & XII sem. 1 \\
\hline Semester II &
\end{tabular}

Tabel 11. Keseteraan Pokok Bahasan Mata Pelajaran Matematika Peminatan kelas XI

\begin{tabular}{|l|c|c|c|c|}
\hline \multirow{3}{*}{ Pokok Bahasan } & \multicolumn{4}{|c|}{ Buku Matematika sesuai Masing-masing } \\
\cline { 2 - 5 } & 2013 & KTSP & KBK & $1994 / 1999$ \\
& & 2006 & 2004 & \\
\hline
\end{tabular}


Tik Ilmeu, VOL.2, NO.2, $2018 \mid \mathbf{1 6 5}$

\begin{tabular}{|l|c|c|c|c|}
\hline Semester I \\
\hline Persamaan Trigonometri & X sem. 2 & X sem. 2 & X sem. 2 & X sem. 1 \\
\hline $\begin{array}{l}\text { Rumus jumlah dan selisih } \\
\text { sudut }\end{array}$ & XII sem. 1 & XI sem. 1 & XI sem. 1 & XI sem. 1 \\
\hline Semester II & XI sem. 2 & XI sem. 1 & XI sem. 1 & XII sem. 1 \\
\hline Lingkaran & XI sem. 1 & XI sem. 2 & XI sem. 2 & XII sem. 1 \\
\hline Suku Banyak/Polinom
\end{tabular}

Tabel 12. Keseteraan Pokok Bahasan Mata Pelajaran Matematika Peminatan kelas XII

\begin{tabular}{|l|c|c|c|c|}
\hline \multirow{2}{*}{ Pokok Bahasan } & \multicolumn{3}{|c|}{ Buku Matematika sesuai Masing-masing Kurikulum } \\
\cline { 2 - 5 } & 2013 & $\begin{array}{c}\text { KTSP } \\
2006\end{array}$ & KBK 2004 & $1994 / 1999$ \\
\hline Semester I & & & \\
\hline Limit fungsi trigonometri & & XI sem. 2 & XI sem. 2 & XI sem. 2 \\
\hline Limit menuju takhingga & XI sem. 2 & & \\
\hline $\begin{array}{l}\text { Turunan fungsi } \\
\text { trigonometri }\end{array}$ & XI sem. 2 & XI sem. 1 & XI sem. 1 & XI sem. 1 \\
\hline Semester II & &
\end{tabular}

Uraian di atas menunjukkan bahwa sebagian besar materi matematika jenjang SMA sesuai dengan kurikulum 2013 revisi 2016, baik wajib maupun peminatan, juga dapat dijumpai pada buku-buku referensi kurikulum sebelumnya. Sebagai pengecualian beberapa materi baru misalnya pertidaksamaan kuadratik dua variabel (Matematika Wajib kelas X semester I) serta distribusi normal dan pengujian hipotesis (Matematika Peminatan kelas XII) tidak dijumpai dalam buku-buku kurikulum sebelumnya.

\section{Penyajian Informasi}

Guna membantu para pemustaka di perpustakaan sekolah, tabel-tabel dalam artikel ini dapat dilengkapi dengan foto-foto sampul buku yang tersedia di perpustakaan sekolah. Tabel dapat disajikan dengan menarik dan diletakkan 
166 | Ezra Putranda Setiawan dan Ismurjanti Ismurjanti: Tabel Pokok...

di tempat yang mudah diakses oleh pemustaka. Contoh penyajian tabel dapat dilihat pada gambar 1 berikut.

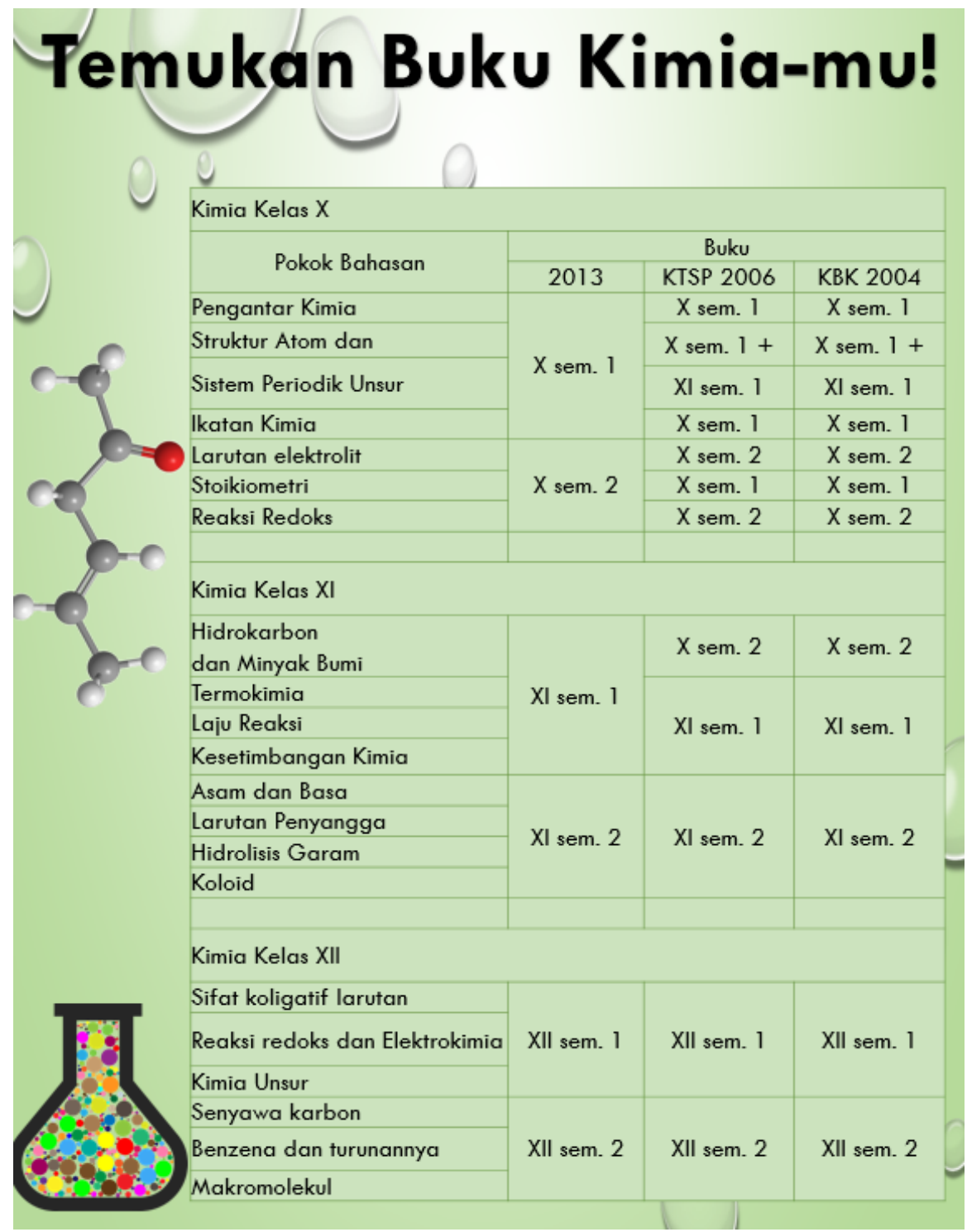

Gambar 1. Contoh Penyajian Tabel Mata Pelajaran (Kimia)

Sebagai catatan, penggunaan buku-buku kurikulum lama ini juga memiliki kelemahan, yakni materi yang tersebar sehingga siswa perlu membaca sejumlah buku (dari jenjang yang berbeda) untuk memperoleh keseluruhan materi dalam satu semester sesuai kurikulum terbaru. Sebagai contoh, berdasarkan tabel 6 di muka, siswa kelas XI pada semester genap 
(semester II) perlu membaca sekurang-kurangnya tiga buku pelajaran pada tingkatan yang berbeda agar dapat memahami seluruh pokok bahasan pada semester tersebut. Oleh karena itu, perpustakaan tetap harus mengupayakan tersedianya buku-buku pelajaran sesuai dengan kurikulum terbaru.

\section{KESIMPULAN}

Dalam penelitian ini telah ditunjukkan bahwa tidak sedikit materi pelajaran jenjang Sekolah Menengah Atas (SMA) sesuai kurikulum 2013 revisi 2016 yang juga dapat ditemukan dalam buku-buku pelajaran SMA sesuai kurikulum sebelumnya. Bagi pustakawan di sekolah, hal ini berarti bahwa perpustakaan sekolah tetap dapat menyediakan buku-buku sesuai kurikulum sebelumnya, terutama selama buku sesuai kurikulum terbaru belum tersedia. Bagi para pe-mustaka, informasi ini dapat membantu mereka menemukan materi atau pokok bahasan yang hendak dipelajari dari bukubuku yang masih tersedia di perpustakaan sekolah. Walaupun demikian, keberadaan buku-buku kurikulum sebelumnya tidak bermaksud menggantikan buku buku referensi sesuai dengan kurikulum terbaru.

Tabel-tabel yang dihasilkan dalam penelitian ini tentu dapat diperluas untuk mencakup materi pelajaran bidang Ilmu Pengetahuan Sosial (IPS), misalnya Ekonomi, Geografi, Sosiologi, dan Sejarah. Untuk pengembangan atau perluasan tersebut, pustakawan sekolah dapat bekerja sama dengan guru masing-masing mata pelajaran.

\section{DAFTAR RUJUKAN}

Khanafi, K. (2013). Penerapan Pendidikan Karakter Dalam Pembelajaran Akhlak (Studi Kasus Di MAN 2 Surakarta Tahun Pelajaran 2012/2013). Skripsi. Surakarta: Universitas Muhammadiyah Surakarta.

Komariah, N. (2009). Peranan Perpustakaan Sekolah dalam Proses Belajar Mengajar. Semiloka pemberdayaan perpustakaan sekolah di Garut. Bandung: Universitas Padjajaran.

Mangnga, A. (2015). Peran Perpustakaan Sekolah terhadap Proses Belajar Mengajar di Sekolah. Jurnal Bidang Kepustakawanan Jupiter. Vol. XIV, no. 1, hal. 38-41.

Munir. (2008). Kurikulum Berbasis Teknologi Informasi dan Komunikasi. Bandung: Alfabeta. 
168 | Ezra Putranda Setiawan dan Ismurjanti Ismurjanti: Tabel Pokok...

Nuriyah. (2017). Ketersediaan Koleksi di Perpustakaan SMA Negeri 1

Serang dan Pengaruh-nya terhadap Siswa Jurusan MIA (Matematika dan Ilmu Alam). Skripsi. Jakarta: Fakultas Adab dan Humaniora, UIN Syarif Hidayatullah.

Rosyada, D. (2004). Perpustakaan sebagai Pusat Pembelajaran: Analisis Arah Perubahan Pendidikan dan Signifikansi Peran Perpustakaan. Makalah disampaikan pada acara Lokakarya Teacher Librarianship. Jakarta: Fakultas Adab dan Humaniora UIN Syarif Hidayatullah.

Susilana, R (ed.). (2006). Kurikulum dan Pembelajaran. Bandung: FIP UPI Bandung.

Wahyuni, M. (2015). Peran Pustakawan sebagai Penyedia Informasi. Jurnal Iqra'. Vol. 9, no. 2, hal. 39-53.

Widuri, E. (2012). Perbandingan Pengajaran Dengan Menggunakan KBK (Kurikulum Berbasis Kompetensi) dan KTSP (Kurikulum Tingkat Satuan Pendidikan). Basastra, Vol 1, no. 1, hal. 48-59.

Wirianto, D. (2014). Persepektif Historis Transformasi Kurikulum di Indonesia. Islamic Studies Jurnal, Vol. 2, no. 1, hal. 133-147.

Yusuf, M. (2017). Peran Pustakawan dalam Meningkatkan Jumlah Kunjungan Peserta Didik di Perpustakaan SMA 4 Bulupoddo Kabupaten Sinjai. Skripsi. Makasar: Fakultas Adab dan Humaniora UIN Alauddin.

Peraturan Menteri Pendidikan dan Kebudayaan Republik Indonesia nomor 20 tahun 2016 tentang Standar Kelulusan Pendidikan Dasar dan Menengah.

Peraturan Menteri Pendidikan dan Kebudayaan Republik Indonesia nomor 21 tahun 2016 tentang Standar Isi Pendidikan Dasar dan Menengah.

Peraturan Menteri Pendidikan dan Kebudayaan Republik Indonesia nomor 22 tahun 2016 tentang Standar Proses Pendidikan Dasar dan Menengah.

Peraturan Menteri Pendidikan dan Kebudayaan Republik Indonesia nomor 23 tahun 2016 tentang Standar Penilaian Pendidikan Dasar dan Menengah. 